University of Nebraska - Lincoln

DigitalCommons@University of Nebraska - Lincoln

USDA National Wildlife Research Center - Staff Publications
U.S. Department of Agriculture: Animal and Plant Health Inspection Service

3-9-2001

\title{
USE OF ACETAMINOPHEN FOR LARGE-SCALE CONTROL OF BROWN TREESNAKES
}

\author{
Peter J. Savarie \\ National Wildlife Research Center \\ John A. Shivik \\ National Wildlife Research Center \\ Gary C. White \\ Colorado State University - Fort Collins, Gary.White@ColoState.edu \\ Jerome C. Hurley \\ National Wildlife Research Center \\ Larry Clark
}

USDA/APHIS/WS National Wildlife Research Center, larry.clark@aphis.usda.gov

Follow this and additional works at: https://digitalcommons.unl.edu/icwdm_usdanwrc

Part of the Environmental Sciences Commons

Savarie, Peter J.; Shivik, John A.; White, Gary C.; Hurley, Jerome C.; and Clark, Larry, "USE OF ACETAMINOPHEN FOR LARGE-SCALE CONTROL OF BROWN TREESNAKES" (2001). USDA National Wildlife Research Center - Staff Publications. 580.

https://digitalcommons.unl.edu/icwdm_usdanwrc/580

This Article is brought to you for free and open access by the U.S. Department of Agriculture: Animal and Plant Health Inspection Service at DigitalCommons@University of Nebraska - Lincoln. It has been accepted for inclusion in USDA National Wildlife Research Center - Staff Publications by an authorized administrator of DigitalCommons@University of Nebraska - Lincoln. 


\title{
USE OF ACETAMINOPHEN FOR LARGE-SCALE CONTROL OF BROWN TREESNAKES
}

\author{
PETER J. SAVARIE, National Wildlife Research Center, 4101 LaPorte Avenue, Fort Collins, CO 80521, USA \\ JOHN A. SHIVIK, ${ }^{1}$ National Wildlife Research Center, 4101 LaPorte Avenue, Fort Collins, CO 80521, USA \\ GARY C. WHITE, Department of Fishery and Wildlife Biology, Colorado State University, Fort Collins, CO 80523, USA \\ JEROME C. HURLEY, National Wildlife Research Center, 4101 LaPorte Avenue, Fort Collins, CO 80521, USA \\ LARRY CLARK, National Wildlife Research Center, 4101 LaPorte Avenue, Fort Collins, CO 80521, USA
}

\begin{abstract}
Because the brown treesnake (Boiga irregularis) has virtually extirpated the avifauna on Guam and is a threat to other Pacific islands, the development of alternative and efficient control methods is required. Therefore, we performed a large-scale field experiment to determine whether the acetaminophen baits we developed could be used to reduce population levels of brown treesnakes on Guam. Toxic baits were made by inserting $80 \mathrm{mg}$ of acetaminophen into dead neonatal mice, and these mouse baits were used to treat plots. Reference plots were baited with unadulterated baits. We used mark-recapture methods to estimate snake abundance on plots before treatment, monitored bait-take rates on treated plots for 30 days, and used mark-recapture to estimate snake populations post-treatment. Bait-take rates were reduced on treated plots by $83 \%$ relative to reference plots after 14 days, when they reached an asymptote. Using a robust design model in program MARK, snakes on reference plots had higher apparent survival rates $(\bar{x}=0.3505)$ than those on treated plots $(\bar{x}=0.0072)$ for the duration of the study, but estimates were influenced by snake movement between plots. When we accounted for movement using a multistrata model, survival on treated plots was estimated as zero. High mobility of brown treesnakes presents difficulty for complete removal of snakes from large areas, but we conclude that acetaminophen baits may provide an effective and selective management tool for quickly and efficiently reducing populations of brown treesnakes on Guam.
\end{abstract}

JOURNAL OF WILDLIFE MANAGEMENT 65(2):356-365

Key words: acetaminophen, Boiga irregularis, brown treesnake, Guam, invasive species, multi-strata model, Program MARK, robust design model.

The brown treesnake is a nocturnal, primarily arboreal, rear-fanged colubrid native to parts of Australia, Indonesia, New Guinea, and the Solomon Islands (Savidge 1987, Greene 1989). After being introduced to Guam in the late 1940s or early 1950s as a stowaway in cargo (Savidge 1987, McCoid 1991, Rodda et al. 1992), the snake population irrupted. Densities may occasionally reach 50-100 snakes/ha (Rodda et al. 1992). The snake has caused the decline and extinction of avifauna and herpetofauna (Savidge 1987, Rodda and Fritts 1992), numerous power outages (Fritts et al. 1987), the loss of domestic animals (Fritts and McCoid 1991), and it is a threat to human health and safety (Fritts et al. 1994). Because it is likely to be transported elsewhere (McCoid et al. 1994, Fritts et al. 1999), it is an invasive species of primary concern (Jaffe 1997; Rodda et al. 1997, 1999a).

With funds provided by the U.S. Department of Defense, the U.S. Department of Agriculture's Wildlife Services has implemented a containment program in areas, such as cargo and military facilities, where snakes have a high likelihood of being trans-

\footnotetext{
${ }^{1}$ E-mail:John.Shivik@usda.gov
}

ported from Guam to other ports. Currently, management tools used in the containment program include traps containing live mouse lures, hand capture, and detector dog teams (Engeman et al. 1998a, b, Linnell et al. 1998; Rodda et al. 1999b), but other methods such as barriers and fumigants have also been investigated (U.S. Department of Agriculture 1996, U.S. Department of the Interior 1999). Traps are the most intensively used management tool, and up to 1,500 traps are regularly maintained (D. S. Vice, Wildlife Services, Guam, personal communication); however, maintenance of live mice as attractants in traps is labor-intensive and expensive. Also, the lure, physical nature of current traps, and various environmental factors may cause biases in the number and size of snakes captured, possibly causing some snakes to be missed during trapping operations (Rodda et al. 1999a, c, Rodda and Fritts 1992; Shivik and Clark 1999a; Shivik et al. 2000a, b). Despite any shortcomings associated with the use of detector dogs, traps, hand capture, and barriers (Rodda et al. 1998), these are currently the only practical techniques available to operational personnel. It is therefore important to continue to identify and develop new and improved control techniques. 
Investigators have documented the attractiveness of odor cues to brown treesnakes (Fritts et al. 1989, Chiszar 1990, Shivik 1998), but odor-only lures are less successful for attracting snakes into traps than multisensory lures (Chiszar et al. 1988, 1997; Shivik and Clark 1999b). Of several types of prey used in traps, live mice appeared to have the most success in capturing snakes in traps (Rodda et al. 1999b). However, Shivik and Clark (1997) documented the attractiveness and practical use of mouse carrion as an inanimate lure for brown treesnakes. In field and laboratory studies, we determined that mouse carrion baits are effective lures and are consumed readily by brown treesnakes on Guam. Under field conditions, few species other than brown treesnakes remove the baits from bait tubes. For example, of 231 bait stations under 24-hr video surveillance, brown treesnakes took $96(42 \%)$ baits and only $2(0.9 \%)$ were taken by another species (monitor lizards, Varanus indicus; P. J. Savarie, National Wildlife Research Center, unpublished data). Because of the attractiveness of mouse carrion baits to brown treesnakes, the selectivity of these baits to brown treesnakes, and the availability of frozen mice from biological supply outlets, we determined that dead neonatal mice were an appropriate bait matrix for delivery of a brown treesnake toxicant.

A variety of attractants (Shivik 1999), repellents (Clark 1997) and toxicants (Brooks et al. 1998) have been screened for use in the control of brown treesnakes. Further pilot studies identified orally delivered acetaminophen as a likely toxicant. Acetaminophen is a drug approved for nomprescription use by the U.S. Food and Drug Administration. Acetaminophen is an ideal candidate for a brown treesnake toxicant because of its widespread availability, low cost, and potential for registration under the Federal Insecticide, Fungicide, and Rodenticide Act, as amended (40 CFR 160). An 80-mg dose of acetaminophen orally delivered to brown treesnakes $(47-300 \mathrm{~g})$ resulted in $100 \%$ mortality within $24 \mathrm{hr}(n=29$; P. J. Savarie, National Wildlife Research Center, unpublished data). Although we have not completed toxicology studies of acetaminophen in brown treesnakes, we suspect that as in mammals, this chemical is likely to have numerous toxic properties subsequent to glutathione depletion, including hepatic necrosis which is probably a component of if not the cause of death in snakes (Gosselin et al. 1984). Our objective was to determine whether a carrion-based delivery system that incorporated an acetaminophen toxicant could attract and kill snakes at levels required to reduce snake populations in a large area.

\section{METHODS}

\section{Bait Stations}

We hereafter refer to the placement of $80 \mathrm{mg}$ of acetaminophen within mouse carrion bait as the treated bait and unadulterated mice carrion as the reference bait. To decrease the likelihood that monitor lizards and the endangered Marianas crow (Corvus kubaryi) would take baits, we placed baits within 10.1 -cm-diameter $\times 30.5$-cm-length sections of white PVC pipes that were suspended about $1.5 \mathrm{~m}$ high in vegetation. Most frequently, baits were used immediately after preparation. Less frequently, for logistical reasons, treated baits were prepared in advance, frozen, and stored for subsequent use in the field. Chemical stability analyses of frozen, stored, and thawed baits indicated that the acetaminophen was chemically stable (John Johnston, National Wildlife Research Center, unpublished data).

\section{Study Area and Spatial Design}

We conducted the large-scale operational evaluation on the Munitions Storage Area, Andersen Air Force Base, Guam. Forested areas within the Munitions Storage Area are transected by access roads in a regular grid pattern (Fig. 1) in a fragmented forest that is well suited for experimentation (Tobin et al. 1999). The 6 plots (about $500 \mathrm{~m}$

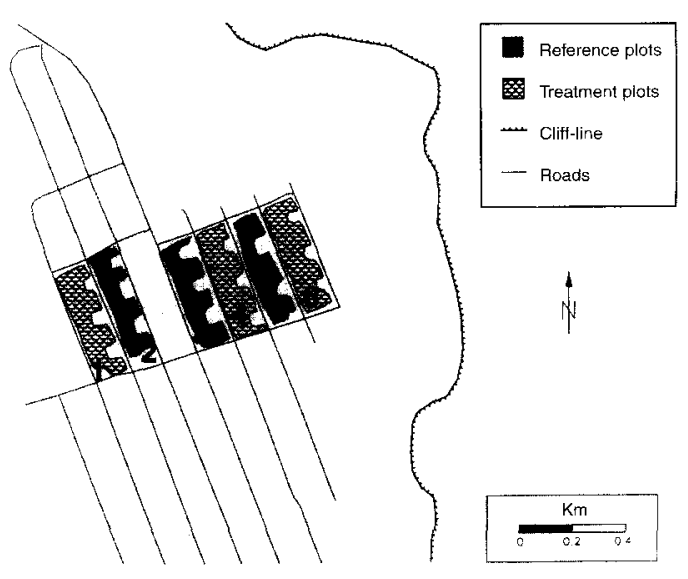

Fig. 1. Spatial layout of reference and treated plots in the Munitions Storage Area, Andersen Air Force Base, Guam, during summer, 1999. Reference plots were baited with unadulterated dead neonatal mice, and treated plots had baits containing $80 \mathrm{mg}$ of acetaminophen. Forested areas are depicted using outlined patterns within the study plots. 
$\times 130 \mathrm{~m}$ each) we selected for study represented semi-isolated plots of similar vegetation structure that were separated by areas of low-quality brown treesnake habitat (e.g., roads and open fields). The area of the plots measured 5.6, 5.3, 5.7, 5.4, 5.6 , and 5.9 ha for plots $1-6$, respectively.

Our previous trapping experience indicated that the base of a cliff-line (Fig. 1) was an area of high snake density. Thus, we suspected that plot 6 would be closest to a large source of snakes. Accordingly, we paired plots starting from the cliff-line and proceeding westward. For each contiguous pair of plots, we randomly assigned a plot to 1 of 2 treatments: treated or reference bait application. The toxicant treatment was assigned to plots 1,4 , and 6 and the reference plots were plots 2,3 , and 5 .

\section{Temporal Design}

Temporally, we designed the study to include the following sequential monitoring and treatment paradigms beginning on 21 June 1999: pretreatment baiting period ( 6 days, cumulative test days 1-6), pretreatment washout (6 days, days 7-12), pretreatment trapping (12 days, days 13-24), treatment (30 days, days 25-54), posttreatment baiting ( 6 days, days 55-60), post-treatment washout (6 days, days $61-66$ ), and posttreatment trapping (12 days, days 67-78). We allowed for a period of no bait availability during the washout periods because of the possibility that resident snakes could be satiated from a continuous availability of mouse baits. During trapping periods we used live mouse lures placed in standard Wildlife Services traps to capture (Linnell et al. 1998), then individually mark snakes with electronic microchips (AVID, Norco, California, USA) and released them at the capture site. During the treatment period, we placed either treated or reference baits at bait stations according to the experimental design.

\section{Bait Placement}

To simulate an operational control effort, we placed baits inside PVC tubes along the forest perimeters of the study plots. We spaced these bait stations at 20-m intervals, and each was left in the same location for pre-, treatment-, and postbaiting periods. Plots $1-6$ had $64,60,60,62,60$, and 63 bait stations, respectively. During the pretreatment, treatment, and post-treatment baiting periods the presence or absence of baits was recorded every 2 days. At that time, new baits were added to empty bait stations, or uneaten baits were removed and replaced with new baits. Thus, the maximum field use of any bait was $\leq 48$ hr throughout the course of the study. The unit of measure during baiting periods was the proportion of baits missing from bait stations as a function of time; hence, the experimental unit was the plot ( $n=3$ per treatment level). To check analysis of variance (ANOVA) assumptions, the proportions were tested for normality and the variances for homogeneity for each treatment level as a function of time. In all cases, the data were not found to differ substantially from being normally distributed and variances were homogeneous. To verify that assignment of plots to treatment categories would not bias analysesi.e., bait take was similar among plots-we analyzed the pretreatment bait-take data using 2-way, fixed-effects ANOVA (STATISTICA 1994) where the 3 sampling days were the repeated measure and assignment category (future designation as a treated or reference treated plot) was the between-measures effect.

Because we anticipated that poisoning would reduce the proportion of baits taken over time, we analyzed the data obtained during the treatment period by using simple contrasts to determine at what day of treatment bait-take rates on reference and treated plots diverged. The pattern over time that baits disappeared from bait stations was empirically described. In the case of the treated bait plots, a modified logistic function was used to characterize the pattern for bait disappearance (STATISTICA 1994); the logistic function used maximized variance explained by the model $\left(R^{2}\right)$ while minimizing the number of parameters estimated. The curves of each of the 3 plots were compared by inspection of the means and standard errors on parameter estimates. Finally, an overall comparison of bait take between the pre- and post-treatment periods was made using a 2-way repeated measures ANOVA. In summary, 3 evaluations of bait take were made: An analysis to assure that the pattern of bait take was similar among reference and treated plots prior to the start of the treatment period; an assessment of the bait-take pattern during the treatment period; and third, a comparison of bait take on plots before and after the administration of the treatment.

\section{Trapping and Mark-Recapture Analysis}

To monitor the number of snakes in each plot, we placed trap stations at 40-m intervals in lines along the perimeter and longitudinally through the midline of each plot. Each trap was hung 
about $1.5 \mathrm{~m}$ high on woody vegetation. Plot $1 \mathrm{had}$ 10 perimeter traps and 10 midline traps (due to the cut-out shape of its vegetation), but all other plots had 11 perimeter and 11 midline traps. No midline traps were $<20 \mathrm{~m}$ from a forest edge. Traps were checked daily.

During pretreatment and post-treatment trapping periods, brown treesnakes were captured and marked by inserting microchips intraperitoneally under ventral scales proximal to the vent. Snakes were identified for sex (by probing hemipenes), measured for snout to vent length, and weighed before they were released at the capture site. Snake-encounter histories were analyzed using program MARK (White and Burnham 1999). Specific parameters of interest included number and survival of snakes on reference and treated plots before and after baiting. We used the robust design model (Kendall and Nichols 1995; Kendall et al. 1995, 1997) to determine apparent survival (probability of survival times probability the animal remains on the study area) between pre- and post-trapping sessions, population size $(N)$ before and after treatment on each plot, as well as initial capture $(p)$ and recapture $(c)$ probabilities. Because only 2 primary trapping sessions were available, the probability of leaving the trapping grid conditional on being on the trapping grid during the previous primary session ( $\gamma$ ") was set to zero, and the probability of remaining off the trapping grid conditional on being off the trapping grid during the previous primary session $\left(\gamma^{\prime}\right)$ never appeared in the model. Models were ranked using AICc and were averaged to determine final parameter estimates using AICc weights (Burnham and Anderson 1998).

Although the spatial design using isolated forest plots was instituted to maximize closure of plots, brown treesnakes in our study area were known to move across roads (Tobin et al. 1999). Therefore, we also used a multi-strata model (Hestbeck et al. 1991, Brownie et al. 1993) to analyze snake movement between adjacent study plots. The multi-strata model included daily apparent survival $(\phi)$, probability of capture and recapture $(p)$, and daily probability of movement to an adjacent plot or to nonadjacent plots $(\psi)$.

\section{RESULTS}

\section{Patterns in Bait Take}

Pretreatment Period.-During the pretreatment bait presentations (cumulative test days $1-6$ ), there

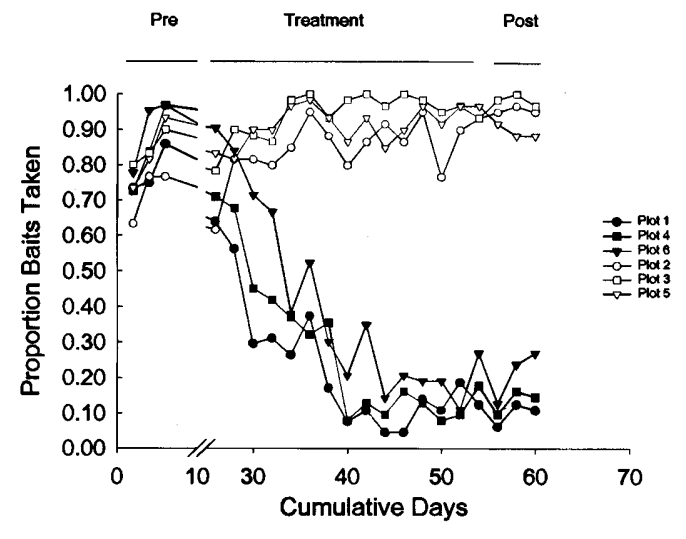

Fig. 2. The proportion of baits taken as a function of time by brown treesnakes on 3 reference plots and 3 treatment plots on Andersen Air Force Base, Guam, during summer, 1999. No treated baits were offered during the pretreatment and posttreatment periods. During the treatment period, acetaminophentreated neonatal mouse carcasses were placed in bait stations (black symbols), and unadulterated carcasses were placed in bait stations on the reference plots (white symbols).

was no plot or plot by time effect $\left(F_{1,4}=0.712, P\right.$ $=0.445$ and $F_{2,8}=0.352, P=0.714$, respectively), suggesting that plots were similar for patterns of bait take. However, there was a tendency for more baits to be taken as a function of time. Overall, the rate of bait disappearance was 0.734 ( $\mathrm{SE}=$ $0.023, n=6)$ at the first bait placement, and it rose to $0.899(\mathrm{SE}=0.029, n=6)$ by the third placement 6 days later $\left(F_{2,8}=22.376, P<0.001\right)$, suggesting that snakes began to preferentially attend to bait stations (Fig. 2). However, there was no indication of a bias in how the plots were to be assigned to subsequent treatment categories.

Treatment period.-At the start of the treatment period, the daily rate of bait disappearance on the treated plots was $0.752(\mathrm{SE}=0.079, n=3)$, while on the reference plots the rate of bait disappearance was $0.744(\mathrm{SE}=0.065, n=3)$. These rates corresponded to the level of bait take first seen in the pretreatment period, suggesting snakes no longer preferentially attended to the bait stations after the 6-day washout and 12-day trapping periods.

Two patterns emerged during the treatment period. First, bait take in the treated plots dropped precipitously relative to the reference plots (Fig. 2, $F_{14,56}=28.612, P<0.001$ ). By the third sampling period ( 6 days after initiation of the poisoning program, cumulative test day 30 ), the number of baits taken on the treated plots was lower than on the reference plots (Fig. 2). 
Table 1. Model values for the relationship between bait take and time on the 3 forest plots treated with acetaminophen baits for brown treesnakes on Guam during summer, 1999. For each plot, the proportion of baits taken was described by $y=y_{0}+a /\left[1+\left(x / x_{0}\right){ }^{b}\right]$, where $y_{0}$ is the minimum asymptotic rate of bait disappearance, $y_{0}+a$ is the maximum asymptotic rate of bait disappearance, $x$ is the cumulative day of the test, $x_{0}$ is the inflection or the day of test where the rate of bait disappearance reaches $50 \%$ of the asymptotic levels, and $b$ is the slope.

\begin{tabular}{|c|c|c|c|c|c|c|}
\hline \multirow[b]{3}{*}{ Value } & \multicolumn{6}{|c|}{ Plot } \\
\hline & \multicolumn{2}{|c|}{1} & \multicolumn{2}{|c|}{4} & \multicolumn{2}{|c|}{6} \\
\hline & Estimate & SE & Estimate & SE & Estimate & $S E$ \\
\hline$a$ & 0.684 & 0.049 & 0.733 & 0.052 & 0.714 & 0.054 \\
\hline$b$ & 8.589 & 2.162 & 8.260 & 1.840 & 11.732 & 2.991 \\
\hline$x_{0}$ & 29.459 & 0.894 & 31.010 & 0.911 & 33.180 & 0.845 \\
\hline$y_{0}$ & 0.101 & 0.027 & 0.112 & 0.030 & 0.196 & 0.029 \\
\hline$R^{2}$ & 0.940 & 0.069 & 0.947 & 0.070 & 0.942 & 0.079 \\
\hline$F_{3,17}$ & 88.168 & & 102.118 & & & 92.132 \\
\hline$P$ & $<0.001$ & & $<0.001$ & & & $<0.001$ \\
\hline
\end{tabular}

Minimum asymptotic rates of bait take were seen 14 days (cumulative test day 38 ) after the initiation of the control program (Fig. 2). After 2 weeks of using acetaminophen baits (cumulative test days $>38$ ), there was an average $93 \%$ bait disappearance on the reference plots (range 77-93\%), indicating the presence of a large number of snakes. In contrast, the mean disappearance of baits on the treated plots was 16\% (range 4-35\%), suggesting a low number of snakes present on these plots. Bait disappearance between the treated and reference plots differed between the pre- and post-treatment periods (Fig. 2 , cumulative test days $\left.1-6,61-66 ; F_{1,4}=293.89, P<0.001\right)$.

The characteristics of bait disappearance within the treated plots differed somewhat among plots (Table 1). The maximum rate of bait disappearance was similar among treated plots, but more baits disappeared closer to the cliff-line (i.e., on plot 6).

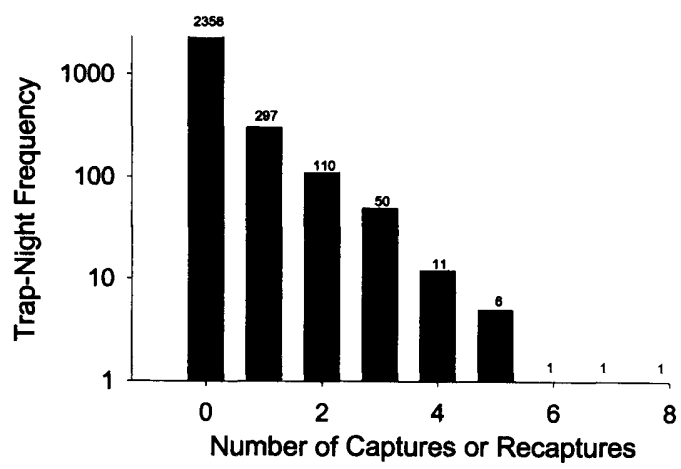

Fig. 3. Frequency distribution of noncaptures by trap, and captures and recaptures for individual brown treesnakes in traps on study plots, Andersen Air Force Base, Guam, 1999.

\section{Empirical Trapping Patterns}

From a total of 3,120 trap-nights on all plots, we recorded 762 captures of 477 snakes, including multiple recaptures (Fig. 3). Snakes ranged from 704 to $1,290 \mathrm{~mm}$ snout to vent length and from 30 to $237 \mathrm{~g}$ at initial capture. As anticipated, higher numbers of snakes were captured on plots closer to the cliff-line (Fig. 4). Fifty-six snakes that were initially captured during the pretreatment trapping were recaptured during the post-treatment period. Fifty-five of these snakes were originally captured on reference plots, and only 1 snake initially captured on a treated plot was recaptured during the post-treatment period.

Application of treated baits to plots substantially reduced the number of snakes captured (Fig. 4).

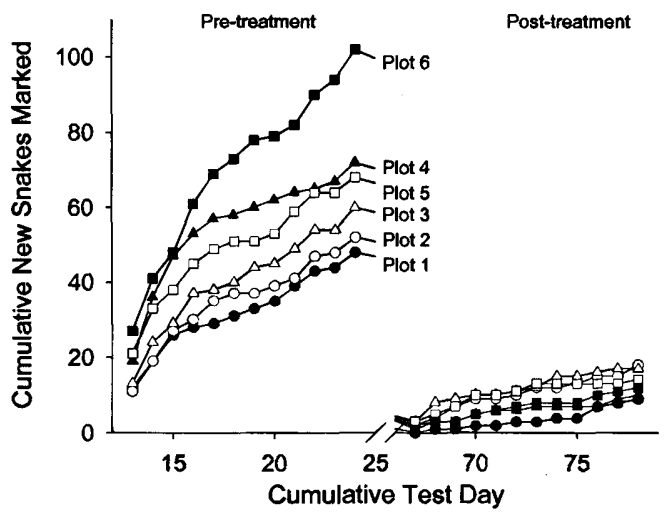

Fig. 4. The cumulative number of new brown treesnakes captured on study plots, Andersen Air Force Base, Guam, as a function of treatment and time. Solid symbols depict plots receiving treated baits during the treatment period. Open symbols depict reference plots. 
Table 2. Model parameters and AICc values for robust design models examining brown treesnake survival and population size from 6 plots ( 3 treated with acetaminophen baits, T, or 3 untreated reference plots, $R$ ) during pretreatment or posttreatment intervals on Andersen Air Force Base, Guam, during summer, 1999.

\begin{tabular}{|c|c|c|c|c|}
\hline Model & $\Delta \mathrm{AlCc}$ & $\begin{array}{c}\text { AlCc } \\
\text { weights }\end{array}$ & $\begin{array}{l}\text { Number of } \\
\text { parameters }\end{array}$ & Deviance \\
\hline$\left\{\text { S(Plot) } p(.) \propto(.) N\left(\text { Session }{ }^{*} \text { Plot }\right)\right\}^{a}$ & 0.00 & 0.34953 & 20 & $1,095.233$ \\
\hline$\left\{\right.$ S(Plot) $p(\text { Session) } c \text {.) } N(\text { Session*Plot })\}^{b}$ & 0.63 & 0.25547 & 21 & $1,093.744$ \\
\hline$\left\{\right.$ S(Treatment) $p\left(\text { Session) } c \text {.) } N\left(\text { Session }{ }^{\star} \text { Plot }\right)\right\}^{c}$ & 1.11 & 0.20066 & 17 & $1,102.658$ \\
\hline$\{\text { S(Treatment) } p(.) c(.) N(\text { Session*Plot })\}^{d}$ & 1.17 & 0.19434 & 16 & $1,104.811$ \\
\hline$\{\text { S(Plot) } p(.)=c(.) N(\text { Session*Plot })\}^{\ominus}$ & 77.89 & 0.00000 & 19 & $1,175.239$ \\
\hline
\end{tabular}

a Survival varies by plot holding initial capture and recapture probabilities constant and estimating population size for each session and plot combination.

b Survival varies by plot with initial capture probability varying by session, recapture probability constant and estimating population size for each session and plot combination.

c Survival varies by treatment with initial capture probability varying by session while holding recapture probability constant and estimating population size for each session and plot combination.

d Survival varies by treatment with initial and recapture probabilities constant and estimating population size for each session and plot combination.

e Survival varies by plot holding initial capture and recapture probabilities constant and equal while estimating population size for each session and plot combination.

During the pretreatment period mean capture rates per trap (mean number of snakes caught per trap night on each of the study plots) $\left(C_{r}\right)$ were similar on plots slated for assignment to the reference and treated categories: $C_{r}=0.331(\mathrm{SE}$ $=0.027, n=3)$ and $C_{r}=0.412(\mathrm{SE}=0.091, n=3)$, respectively. After the application of the control program, the mean per trap capture rate was reduced on plots: $C_{r}=0.175(\mathrm{SE}=0.025, n=3)$, and $C_{r}=0.054(\mathrm{SE}=0.007, n=3)$ for the reference and treated plots, respectively.

The location of traps relative to the perimeter or interior for the plot sizes studied had no obvious effect on trap-capture rates. During the pretreatment period, trap-capture rate on the perimeter $C_{r}=0.367(\mathrm{SE}=0.064, n=6)$ was similar to that on the midline $C_{r}=0.361(\mathrm{SE}=0.037$, $n=6)$. The treatment regimen did not affect the similarities for trap-capture probability between perimeter and midline traps. For example, during the post-treatment period, capture rates per trap for the perimeter and midline were $C_{r}=$ $0.131(\mathrm{SE}=0.031 \mathrm{SE}, n=6)$ and $C_{r}=0.099(\mathrm{SE}$ $=0.029, n=6$ ), respectively.

\section{Population Size and Survival Estimates}

The minimum AICc robust design model included survival rate by plot, initial and recapture probabilities constant across days within a session, and population size estimates for each plot before and after treatment (Table 2). Model-averaged values indicated initial population sizes of 52-113 snakes within each treatment plot for the pretreatment period (Table 3, Fig. 4). During the post-treatment period, population size ranged from 34-48 snakes on reference plots and 11-13 snakes on treated plots. Apparent survival between trapping occasions varied also, with snakes on reference plots having higher apparent survival rates $(\bar{x}=0.3536)$ than those on treated plots $(\bar{x}=0.0070$; Table 4$)$.

Because reference plots appeared to be influenced by toxic treatments on treated plots, we used program MARK to conduct a multi-strata design incorporating snake movement between reference and treatment plots. The minimum AICc model provided estimates of survival on reference and treatment plots during nontreatment periods, survival on the treated plots during the treatment periods, and movement to adjacent vs. not adjacent plots. We assumed the probability of initial capture to be equal in all areas (Table 5). Snakes moved between plots, with a daily movement probability of $0.0080(\mathrm{SE}=0.0021)$ to a physically adjacent study plot per day, i.e., each snake had a 0.0923 probability $(\mathrm{SE}=0.0238)$ of moving to an adjacent study plot during the 12day trapping period. When adjusted to account for snakes that were initially captured on treatment plots during the pre-baiting period, survival 
Table 3. Population estimates for brown treesnakes on 6 study plots ( 3 treated with acetaminophen baits, T, or 3 untreated reference plots, R) on Andersen Air Force Base, Guam, during summer, 1999. Estimates are from model-averaged robust design models in program MARK.

\begin{tabular}{|c|c|c|c|c|c|c|}
\hline \multirow[b]{2}{*}{ Plot } & \multicolumn{3}{|c|}{ Pretreatment } & \multicolumn{3}{|c|}{ Post-treatment } \\
\hline & $\hat{N}$ & SE & $95 \% \mathrm{Cl}$ & $\hat{N}$ & SE & $95 \% \mathrm{Cl}$ \\
\hline $1-T$ & 51.84 & 2.69 & $46.56-57.11$ & 10.95 & 1.43 & $8.14-13.75$ \\
\hline $2-R$ & 52.95 & 2.73 & $47.61-58.29$ & 35.08 & 2.87 & $29.44-40.71$ \\
\hline 3-R & 65.20 & 3.08 & $59.16-71.25$ & 47.71 & 3.55 & $40.75-54.67$ \\
\hline $4-T$ & 79.68 & 3.48 & $72.86-86.51$ & 10.95 & 1.43 & $8.15-13.75$ \\
\hline $5-R$ & 76.34 & 3.39 & $69.69-82.99$ & 33.93 & 2.81 & 28.42-39.44 \\
\hline $6-T$ & 113.10 & 4.35 & $104.56-121.63$ & 13.08 & 1.54 & $10.05-16.10$ \\
\hline
\end{tabular}

estimates for treatment and reference plots differed considerably. Daily survival rate was close to 1.0 on reference plots $(0.9896, \mathrm{SE}=\mathbf{0 . 0 0 2 4})$ and was zero on treatment plots (Table 5).

\section{DISCUSSION}

Based on these results, we are confident that acetaminophen baits are an effective tool for drastically reducing brown treesnake populations in fragmented forest areas, but acknowledge that brown treesnakes were not extirpated due to a high degree of movement between plots. The toxicants, however, may have been more effective than we had initially thought, because there were declines in population size on the 3 nearby reference plots even though they were not treated directly.

The lower post-treatment trapping rates even on the reference plots (Fig. 4) have several explana-

Table 4. Apparent survival estimates between pretreatment and post-treatment trapping sessions for brown treesnakes on 6 study plots on Andersen Air Force Base, Guam, during summer, 1999. Between the 2 trapping sessions, baits containing acetaminophen were placed in treated plots $(T)$ but reference plots $(\mathrm{R})$ contained unadulterated baits ${ }^{\mathrm{a}}$.

\begin{tabular}{cccc}
\hline Plot & $\hat{S}$ & SE & $95 \% \mathrm{Cl}$ \\
\hline $1-\mathrm{T}$ & 0.0168 & 0.0203 & $0.0015-0.1602$ \\
$2-\mathrm{R}$ & 0.3273 & 0.0622 & $0.2120-0.4679$ \\
$3-\mathrm{R}$ & 0.4333 & 0.0925 & $0.2677-0.6154$ \\
$4-\mathrm{T}$ & 0.0021 & 0.0036 & $0.0001-0.0628$ \\
$5-\mathrm{R}$ & 0.3003 & 0.0685 & $0.1846-0.4486$ \\
$6-\mathrm{T}$ & 0.0021 & 0.0036 & $0.0001-0.0628$ \\
\hline
\end{tabular}

a Estimates were constructed using model-averaged robust design models in program MARK with confidence intervals based on a logit transform, and do not account for movement of snakes out of the study area and onto treatment plots. tions but were most likely due to a carryover effect from movement patterns of snakes. It is arguable that the reduced number of new snakes captured on the reference plots during the posttreatment period resulted from a reduced probability of immigration while emigration probability (going to a treated plot) remained constant. For example, if one assumes that the probability of moving to an adjacent plot was 0.0080 per day, and for plots 2 and 3, 1 of the adjacent plots was a treated plot from which no snake returns or originates, the population estimate at the end of 30 days of treatment was 43.4 and 52.2 snakes, respectively. This compares favorably with values presented in Table 3. Plot 5 was adjacent to 2 treated plots. After 30 days the estimated population was 30.5; again, this value compares favorably to the estimate in Table 3 . Thus, it is reasonable to infer that the reduced populations of

Table 5. Daily survival and movement estimates for brown treesnakes on 6 study plots on Andersen Air Force Base, Guam, during summer, 1999. Estimates are from the multistrata design model in program MARK for the minimum AICC model having the 5 parameters shown in the table.

\begin{tabular}{lllc}
\hline Parameter & Estimate & SE & $95 \% \mathrm{Cl}$ \\
\hline $\begin{array}{c}\text { Survival during nontreat- } \\
\text { ment periods, all plots }\end{array}$ & 0.9896 & 0.0024 & $0.9836-0.9934$ \\
$\begin{array}{c}\text { Survival on treatment plot } \\
\text { during treatment phase }\end{array}$ & 0.0000 & 0.0000 & \\
$\begin{array}{c}\text { Probability of capture on } \\
\text { all plots }\end{array}$ & 0.0618 & 0.0043 & $0.0538-0.0707$ \\
$\begin{array}{c}\text { Probability of movement } \\
\text { to adjacent plot }\end{array}$ & 0.0080 & 0.0021 & $0.0048-0.0135$ \\
$\begin{array}{c}\text { Probability of movement } \\
\text { to nonadjacent plot }\end{array}$ & 0.0000 & 0.0000 & \\
\hline
\end{tabular}


snakes on the reference plots were a result of carry-over effects attributable to the juxtaposition of reference and treated plots.

The 1 snake that was marked in a treated plot and survived the treatment baiting had an interesting capture history, which highlights the importance of accounting for snake movement. This snake was captured 5 times: initially on a treatment plot and then twice on the adjacent reference plot before application of the treatment; after poisoning, the snake was again captured on the reference plot before it moved to the treatment plot, where it was captured for the last time.

We recognize that the population estimates produced from the robust design model are likely biased, probably high, because of the immigration of snakes onto the plots during the 12-day trapping sessions and lack of geographic closure. However, the model used to estimate population size operates under the assumption that each individual has the same capture probability, not allowing individual heterogeneity. Typically, population estimates from such a scenario are biased low (Otis et al. 1978). Thus, without data from an experiment designed specifically to detect movement of snakes onto and off the study plots, and the resulting estimate of the rates of immigration and emigration for a study plot, we cannot quantitatively assess the bias of the population size estimates.

Overall, bait take was a good indicator of the number of snakes found within a plot (Figs. 2, 4; Table 3). Interestingly, bait take reached an asymptote at about $16 \%$ in treated plots. This value also corresponds with high movement rates between study plots seen in mark-recapture models. Based on this study, and work by Tobin et al. (1999), who found that $77 \%$ of radiomarked snakes crossed a road during 3-4 months of observation, roads and areas barren of vegetation and covered with asphalt are not an effective barrier to snake movement.

\section{MANAGEMENT IMPLICATIONS}

Because trapping is an effective but logistically limited tool for managing brown treesnakes, toxic bait stations may augment the abilities of control personnel. Furthermore, because smaller snakes are attracted to carrion (Shivik and Clark 1999a), it is possible that toxic mouse carrion baits may be more effective for treating brown treesnake populations in the long term because these baits will remove snakes before they achieve reproductive size.
We were able to drastically reduce snake populations quickly and to bring survival to near zero. Because of the large degree of movement shown by brown treesnakes in this and other studies (Tobin et al. 1999), however, we were unable to extirpate brown treesnakes from our plots. Furthermore, we are collecting preliminary evidence suggesting that our study plots returned to former snake densities within 6 months after treatment. Ultimately, unless snakes are prevented from reinvading cleared areas, the effects of small-scale population reduction efforts may be short lived. Enclosing large areas with barriers (Campbell 1999) could eliminate movement, drastically increase the effectiveness of toxic baits, and enhance the permanence of population reduction. Because individual snakes are equally likely to be captured in either perimeter or interior traps, and because our perimeter-only baiting regimen had large effects on entire populations, it may not be necessary to establish logistically difficult toxic-bait or trapping stations on smaller or similarly sized plots (Engeman and Linnell 1998). Wide-scale broadcast of baits (e.g., using aircraft) may be required for effective treatment of the interior of large or inaccessible areas. However, a toxicant must first follow U.S. Environmental Protection Agency registration guidelines before being used operationally. We believe that a combined management approach incorporating trapping, toxic baits, and barriers could be instituted to allow the efficient clearing of large areas of brown treesnakes and ultimately the successful reintroduction of native species.

\section{ACKNOWLEDGMENTS}

We thank K. G. Dyer, K. A. Fagerstone, K. S. Gruver, T. J. Linder, and D. L. York for assistance in the field and D. S. Vice and M. E. Pitzler for help and logistical support. We appreciate the continued efforts and help from $\mathrm{H}$. Hirsh and others at Andersen Air Force Base, Guam. Also, the comments of R. L. Bruggers, M. W. Fall, T. H. Fritts, G. H. Rodda, and D. S. Vice on the manuscript were especially helpful. This operational evaluation was conducted with funds provided to the National Wildlife Research Center by the U.S. Department of Defense under Legacy Project Number 18, "Field Evaluation of Chemical Methods for Brown Treesnake Management," and the sustained support of the Legacy Program is greatly appreciated as was auxiliary funding from the Department of the Interior. All trapping and work herein were performed with the approval of 
the National Wildlife Research Center Institutional Animal Care and Use Committee.

\section{LITERATURE CITED}

Brooks, J. E., P. J. SAVARIE, AND J. J. JohnSton. 1998. The oral and dermal toxicity of selected chemicals to brown treesnakes (Boiga irregularis). Wildlife Research 25:427-435.

Brownie, C., J. E. Hines, J. D. Nichols, K. H. Pollock, AND J. B. Hestbeck. 1993. Capture-recapture studies for multiple strata including non-Markovian transitions. Biometrics 49:1173-1187.

BURNHAM, K. P., AND D. R. ANDERSON. 1998. Model selection and inference-a practical information-theoretic approach. Springer-Verlag, New York, USA.

CAMPBELL, E. W., III. 1999. Barriers to movements of the brown treesnake (Boiga irregularis). Pages 306-312 in G. H. Rodda, Y. Sawai, D. Chiszar, and H. Tanaka, editors. Problem snake management: the habu and the brown treesnake. Cornell University Press, Ithaca, New York, USA.

CHISZAR, D. 1990. The behavior of the brown treesnake: a study in applied comparative psychology. Pages 101-123 in D. A. Dewsbury, editor. Contemporary issues in comparative psychology. Sinauer Associates, Sunderland, Massachusetts, USA.

一, K. KANDLER, AND H. M. SMITH. 1988. Stimulus control of predatory attack in the brown treesnake (Boiga irregularis) 1. Effects of visual cues arising from prey. Snake 20:151-155.

$\longrightarrow$, G. H. RodDA, AND H. M. SMITH. 1997. Experiments on chemical control of behavior in brown treesnakes. Pages 121-127 in J. R. Mason, editor. Repellents in wildlife management: proceedings of a symposium. National Wildlife Research Center, Fort Collins, Colorado, USA.

Clark, L. 1997. Responsiveness of brown treesnakes to odors. Pages 129-138 in J. R. Mason, editor. Repellents in wildlife management: proceedings of a symposium. National Wildlife Research Center, Fort Collins, Colorado, USA.

ENGEMAN, R. M., AND M. A. LINNELl. 1998. Trapping strategies for deterring the spread of brown tree snakes from Guam. Pacific Conservation Biology 4:348-353.

- - D. V. Rodriguez, K. S. Gruver, W. S. SANTOS, AND M. E. PitZler. 1998 a. Effectiveness of the detector dogs used for deterring the dispersal of brown treesnakes. Pacific Conservation Biology $4: 256-260$

$\longrightarrow,-$ D. S. Vice, AND M. E. Pitzler. $1998 b$. Efficacy of the methods used in an integrated program to deter the spread of brown treesnakes from Guam. Proceedings of the Australian Vertebrate Pest Conference 11:435-440.

FritTs, T. H., AND M. J. McCoID. 1991. Predation by the brown tree snake Boiga irregularis on poultry and other domesticated animals in Guam. Snake 23:75-80.

$\longrightarrow,-$ AND D. M. GoMEz. 1999. Dispersal of snakes to extralimital islands: incidents of the brown treesnake (Boiga irregularis) dispersing to islands in ships and aircraft. Pages 209-223 in G. H. Rodda, Y. Sawai, D. Chiszar, and H. Tanaka, editors. Problem snake management: the habu and the brown treesnake. Cornell University Press, Ithaca, New York, USA.
, AND R. L. HADDOCK. 1994. Symptoms and circumstances associated with bites by the brown tree snake (Colubridae: Boiga irregularis) on Guam. Journal of Herpetology 28:27-33.

, N. J. ScotT, JR., AND J. A. SAVIDGE. 1987. Activity of the arboreal brown tree snake (Boiga irregularis) on Guam determined by electrical outages. Snake 19:51-58.

$\longrightarrow,-$ AND B. E. SMITH. 1989. Trapping Boiga irregularis on Guam using bird odors. Journal of Herpetology 23:189-192.

Gosselin, R. E., R. P. SMith, ANd H. C. Hodge. 1984. Clinical toxicology of commercial products. Williams and Wilkins, Baltimore, Maryland, USA.

GREENE, H. W. 1989. Ecological, evolutionary, and conservation implications of feeding biology in old world cat snakes, genus Boiga (Colubridae). Proceedings of the California Academy of Sciences 46:193-207.

HestBeck, J. B., J. D. Nichol.s, AND R. A. MALeCKI. 1991. Estimates of movement and site fidelity using markresight data of wintering Canada geese. Ecology 72:523-533.

JAFFE, M. 1997. And no birds sing. Barricade Books, New York, USA.

KENDALl, W. L., AND J. D. Nichols. 1995. On the use of secondary capture-recapture samples to estimate temporary emigration and breeding proportions. Journal of Applied Statistics 22:751-762.

$\longrightarrow,-$ AND J. E. HiNES. 1997. Estimating temporary emigration using capture-recapture data with Pollock's robust design. Ecology 78:563-578.

, K. H. Pollock, ANd C. Brownie. 1995. A likelihood-based approach to capture-recapture estimation of demographic parameters under the robust design. Biometrics 51:293-308.

LindberG, A. C., J. A. Shivik, AND L. Clark. 2000. Mechanical mouse lure for brown treesnakes. Copeia 2000:886-888.

Linnell, M. A., R. M. Engeman, M. E. Pitzler, M. O. WATtON, G. F. WhITEHEAD, AND R. C. MILLER. 1998. An evaluation of two designs of stamped metal trap flaps for use in operational trapping of brown treesnakes (Boiga irregularis). Snake 28:14-18.

MCCoID, M.J. 1991. Brown treesnake (Boiga irregularis) on Guam: a worst case scenario of an introduced predator. Micronesica 3:63-69.

-, T. H. FritTS, AND E. W. CAMPBELL, III. 1994. A brown tree snake (Colubridae: Boiga irregularis) sighting in Texas. Texas Journal of Science 46:365-368.

Otis, D. L., K. P. BurnhaM, G. C. White, AND D. R. ANDERSON. 1978. Statistical inference from capture data on closed animal populations. Wildlife Monographs 62.

RODDA, G. H., AND T. H. FRITTs. 1992. Sampling techniques for an arboreal snake, Boiga irregularis. Micronesica 25:23-40.

$\longrightarrow,-$ AND E. W. CAMPBELL, III. $1999 c$. The feasibility of controlling the brown treesnake in small plots. Pages 468-477 in G. H. Rodda, Y. Sawai, D. Chiszar, and H. Tanaka, editors. Problem snake management: the habu and the brown treesnake. Cornell University Press, Ithaca, New York.

$\longrightarrow,-$, AND D. CHISZAR. 1997. The disappearance of Guam's wildlife. Bioscience 47:565-574.

- , C. S. Clark, S. W. GotTe, AND D. Chiszar. $1999 \mathrm{~b}$. A state-of-the-art trap for the brown treesnake. 
Pages 268-305 in G. H. Rodda, Y. Sawai, D. Chiszar, and $H$. Tanaka, editors. Problem snake management: the habu and the brown treesnake. Cornell University Press, Ithaca, New York, USA.

$\longrightarrow, \longrightarrow$, AND P. J. CONRY. 1992. Origin and population growth of the brown treesnake, Boiga irregularis, on Guam. Pacific Science 46:46-57.

G. Perry, AND E. W. CampBell, III. 1998.

Managing island biotas: can indigenous species be protected from introduced predators such as the brown treesnake? Transactions of the North American Wildlife and Natural Resources Conference 63:95-108.

- Y. SawaI, D. Chiszar, AND H. TANaKa, editors. 1999a. Problem snake management: the habu and the brown treesnake. Cornell University Press, Ithaca, New York, USA.

SAVIDGE, J. A. 1987. Extinction of an island forest avifauna by an introduced snake. Ecology 68:660-668.

SHrvik, J. A. 1998. Brown treesnake response to visual and olfactory cues. Journal of Wildlife Management 62:105-111.

2.1999. Carrion, context, and lure development: the relative importance of sensory modalities to foraging brown treesnakes (Boiga irregularis). Dissertation, Colorado State University, Fort Collins, USA.

$\longrightarrow$, J. BOURASSA, AND S. N. DONNIGAN. 2000 $b$. Elicitation of brown treesnake predatory behavior using polymodal stimuli. Journal of Wildlife Management 64:969-975.

, AND L. CI.ARK. 1997. Carrion seeking in brown treesnakes: importance of olfactory and visual cues. Journal of Experimental Zoology 279:549-553. , AND —. 1999a. Ontogenetic shifts in car- rion attractiveness to brown treesnakes (Boiga irregularis). Journal of Herpetology 33:334-336.

, AND $1999 \mathrm{~b}$. The development of chemosensory attractants for brown treesnakes. Pages 649-654 in R. E. Johnston, D. Müller-Schwarze, and P. W. Sorensen, editors. Advances in chemical signals in vertebrates. Plenum Publishers, New York, USA

, W. G. WRIGHT, AND L. Clark. 2000a. Seasonal variability in brown treesnake (Boiga irregularis) response to lures. Canadian Journal of Zoology 78:79-84.

STATISTICA. 1994. StatSoft, Incorporated. Tulsa, Oklahoma, USA.

Tobin, M. E., R. T. Sugihara, P. A. Pochop, AND M. A. LINNELL. 1999. Nightly and seasonal movements of Boiga irregularis on Guam. Journal of Herpetology 33:281-291.

U.S. Department of Agriculture. 1996. Brown treesnake control activities on Guam. Environmental assessment. U.S. Department of Agriculture, Washington, D.C., USA.

U.S. DEPARTMENT OF THE INTERIOR. 1999. Integrated pest management approaches to preventing the dispersal of the brown treesnake and controlling snakes in other situations. U.S. Department of the Interior, Washington, D.C., USA.

White, G. C., And K. P. Burnham. 1999. Program MARK: survival estimation from populations of marked animals. Bird Study 46 Supplement:120-138.

Received 18 May 2000.

Accepted 30 August 2000.

Associate Editor: Rattner. 